Carolina, Florida and the Bahama Islands . . by Marc Catesby. London, Innys, fol. Vol. I, I731 ; Vol. 2, I 743, tab. 200. Appendix I748; tab. 20.

Edition 2 by George Edwards. London, I754.

“ 3 by George Edwards. London, i77r.

Vol. I. pl. 8 Gryllotalpa columbia Scudd.

35 Ecpantheria oculatissima S. \& A.

66 A fly; not recognizable. Vol. 2. pl. 83 Papilio turnus Linn.

84 Attacus luna Linn.

86 " cecropia Linn. and cocoon.

88 Danaus plexippus Linn.

89 Oedipoda carolina De Geer.

90 Attacus cecropia Linn.
9I A. polpyhemus Cram.

94 Eacles imperialis Drury. Larva.

95 Thais rumina Linn.

96 Deiopeia bella Linn.

97 Papilio turnus Linn.

IOO " marcellus B. \& L.

Appdx. pl. 4 Thalessa atrata Fabr.

5 Pelopoeus caeruleus Linn.

Io f. 3 Pulex penetrans Linn.

$4 \mathrm{~A}$ beetle I have not been able to identify.

5 Blatta americanaLinn.

9 " ? not known to me.

7 Silpha peltataCatesby.

I I Canthon laevis Drury. Phanaeus carnifex Linn.

I3 Sphex cementaria Drury.

I5 Mutilla coccinea Fabr.?

\title{
NOTES ON THE LARVAL STAGES OF SAMIA CYNTHIA.
}

\author{
By CAROLINE G. SOULE, BROOKLINE, MASS.
}

The eggs of Cynthia, except a very few, did not turn green before hatching. Those laid first, Ioth May, hatched on 3Ist May, giving 2I days for the eggperiod; but those laid last, I8th May, hatched on 3 d June, giving 16 days for this period.

The larvae ate very little till the middle of the second day, and did not eat the egg-shell at all, unless they ate the bits removed to let them out.

When very young they seemed to be troubled by the excrement, which clung to the anal shield, instead of dropping in the usual manner, and the larvae had a way of seizing the excreta with their mouths, pulling them free, and then giving them a quick jerk which threw them over the edge of the leaf. There was a little silk visible all through the first stage, where the larvae moved.

About I 20 eggs I gave away, of the remaining 221 only two failed to hatch.

I gave most of the larvae tulip-tree (Liriodendron tulipifera), leaves, which they ate eagerly. 
With some I tried lilac, pear, Pyrusjaponica, walnut, and horse-chestnut, and at first they seemed to like them, except the horse-chestnut, but the second day they only nibbled at these leaves, and several larvae died.

To others I gave Lonicera tartarica and bittersweet (Solanum dulcamara,) and these they ate fairly well, but did not grow as large as those on tulip-tree, though they moulted at the same times.

Moulting began on 7 th June, seven days from the hatching of the first eggs.

The second moulting of the firstborn larvae began on $9^{\text {th }}$ June, only two days from the first moulting, and before the last larvae had finished their first moulting.

The $3^{\text {rd moulting began }}$ ith June, five days from the second, and before the last larvae had accomplished their second moulting.

The $4^{\text {th }}$ moulting began on 17 th June, before the last larvae had finished the $3^{\text {rd }}$ moulting. The green color appeared for the first time, and the anal shield was bright orange edged with pale blue. Several died in moulting, and for no apparent cause.

On the night of 3oth June two larvae began spinning, and by four P. M. on
Ist July their cocoons were thick, while several others had begun to spin, making their larval life just one month.

The largest of these larvae weighed ${ }_{4}^{1} \mathrm{oz}$. each and were three inches long, or lacked a trifle of that length. The smallest, those fed on Lonicera tartarica were one and a quarter inches long and weighed very little-less than my letter-scales would weigh; their moults corresponded with those of the fullgrown larvae, and they reached the same coloring and markings, except the orange anal shield, with the blue edge, and the other blue markings.

Their development seemed to be retarded as well as their size stunted by the food-plant.

Although the dwarfs moulted at the same time with the large larvae of the same age, the two which survived the last moult fed until the last part of July, when one died, and the other began to spin 3 ist July. After various futile attempts he gave it up, and, on 8th Aug., pupated on the bottom of the tin, without any trace of silk about him. The pupa was bright yellow, turning brown gradually.

None of the larvae fed on tulip-tree made as heavy cocoons as those fed on Ailanthus, from which these were bred. 

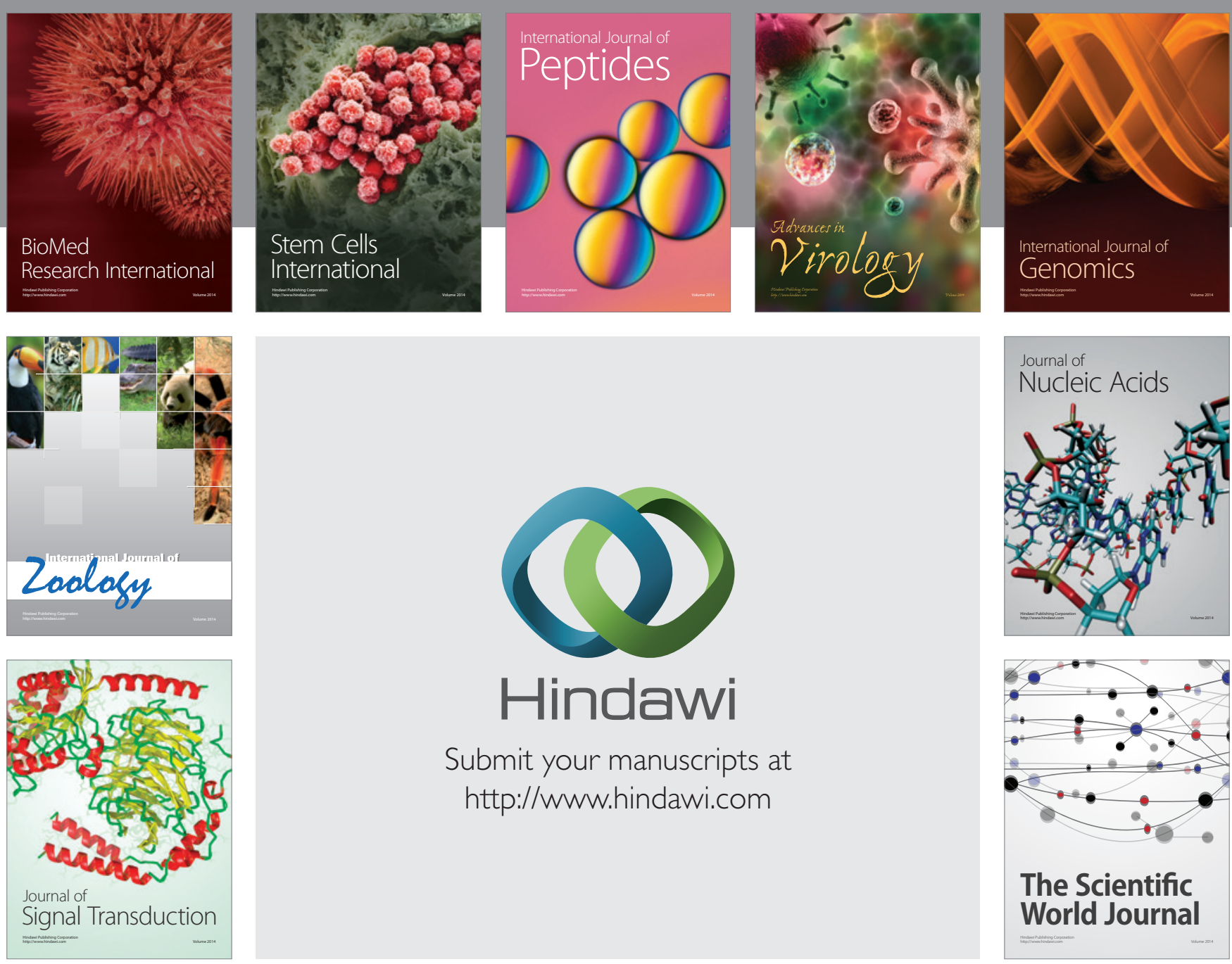

Submit your manuscripts at

http://www.hindawi.com
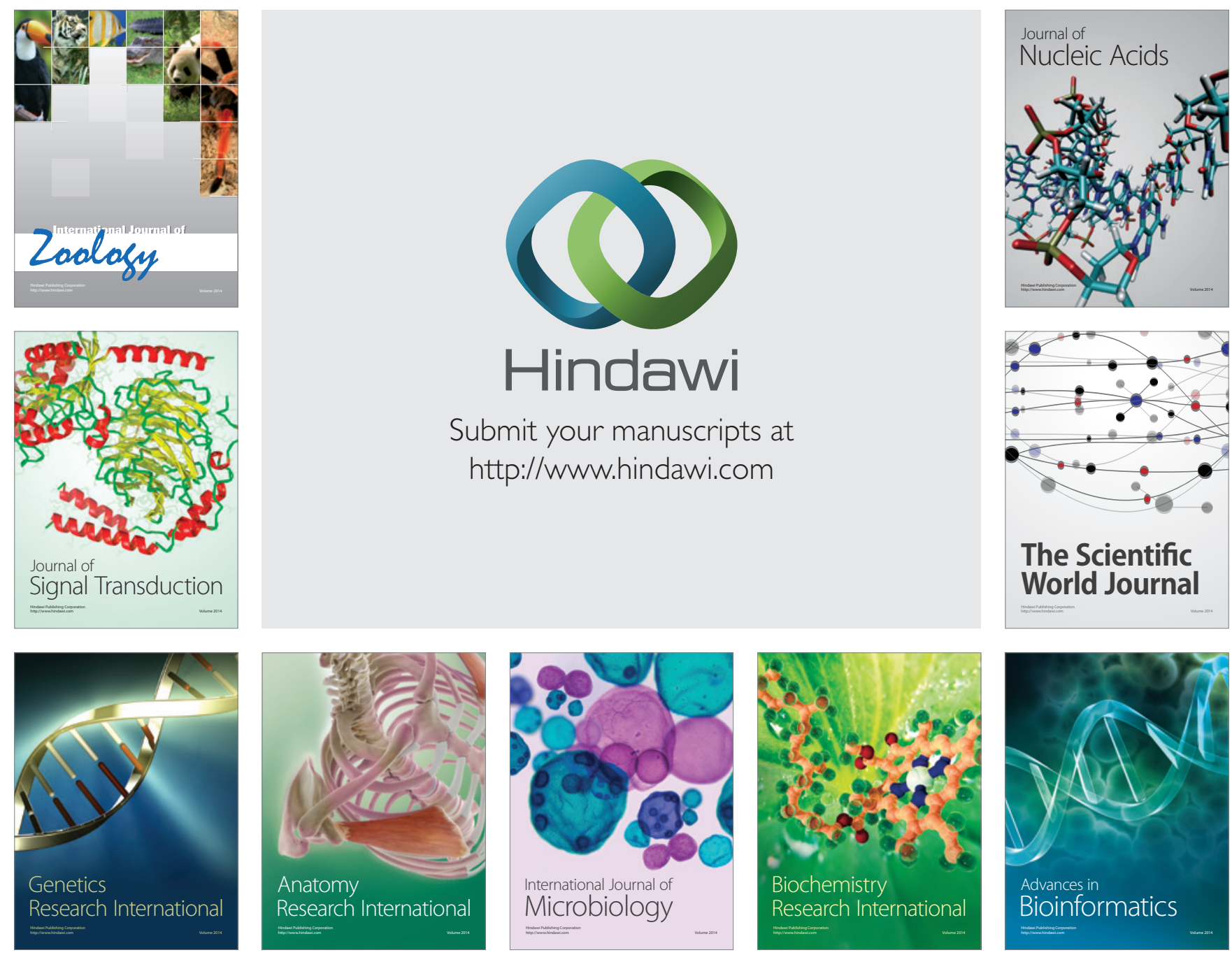

The Scientific World Journal
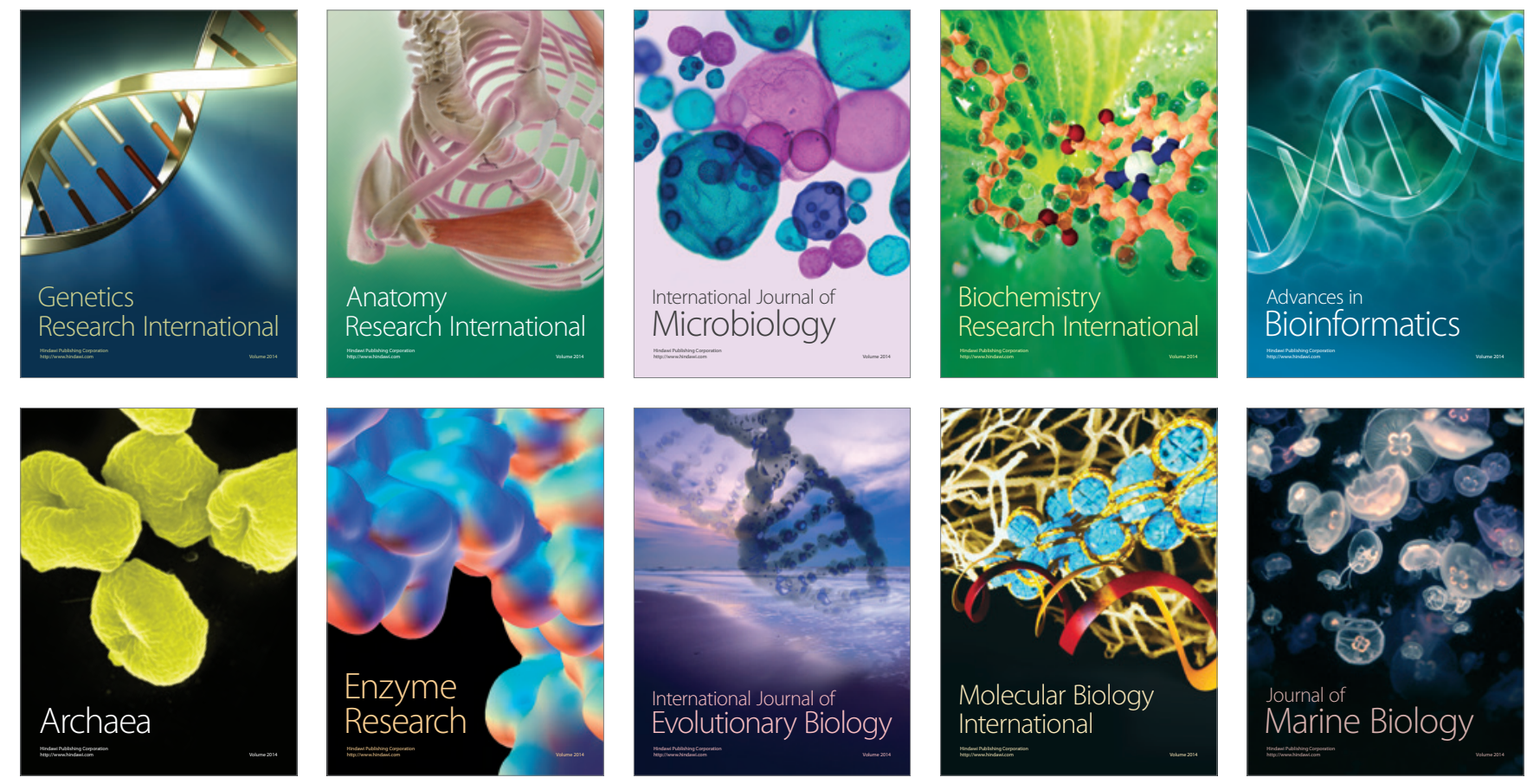